\title{
Hydrogeological investigations of river bed clogging at a river bank filtration site along the River Warta, Poland
}

\author{
Jan Przybyłek, Krzysztof Dragon*, Piotr Michał Jan Kaczmarek \\ Adam Mickiewicz University, Institute of Geology, Krygowskiego 12, 61-680 Poznań, Poland \\ *corresponding author, e-mail: smok@amu.edu.pl
}

\begin{abstract}
River bank filtration (RBF) is a system that enriches groundwater resources by induced infiltration of river water to an aquifer. Problematic during operation of RBF systems is the deterioration of infiltration effectiveness caused by river bed clogging. This situation was observed in the Krajkowo well field which supplies fresh water to the city of Poznań (Poland) during and after the long hydrological drought between the years 1989 and 1992. The present note discusses results of specific hydrogeological research which included drilling of a net of boreholes to a depth of $10 \mathrm{~m}$ below river bottom (for sediment sampling as well as for hydrogeological measurements), analyses of grain size distribution and relative density studies. The results obtained have allowed the recognition of the origin of the clogging processes, as well as the documentation of the clogged parts of the river bottom designated for unclogging activities.
\end{abstract}

Key words: cone of depression, dynamic water level changes, groundwater resources

\section{Introduction}

Deterioration of hydraulic properties of porous media that is caused by transport of suspended materials in water is a serious problem; this is especially important for river bank filtration (RBF) sites, where river water enters the aquifer (Hiscock \& Grischek, 2002). The river water contains suspended solids, such as fragments of quartz and feldspar, clay minerals, vegetable fibres, humic substances, micro-organisms and lifeless algae etc., which are transported into the porous river bed and cause clogging (Sharma \& Yortos, 1987; Górski \& Przybyłek, 1992; Górski et al., 1993; Trzaska \& Sobowska, 2000; Skolasińska, 2006, 2007; Sroka et al., 2014). This process reduces the hydraulic conductivity of the river bed and thus limits infiltration of surface water into the aquifer, which is especially impor- tant for RBF (Rinck-Pfeiffer et al., 2000; Hubbe et al. 2009; Sprenger et al., 2011; Ulrich et al., 2015; Grischek \& Bartak, 2016).

River bed material plays an important role as a natural filter for treatment of river water during RBF. Removal of the contamination load from the river water during infiltration is linked to numerous processes such as filtration, sedimentation, coagulation, ion exchange, sorption, etc. that occur in the river bed sediments and then in the aquifer (Kowal \& Świderska-Bróz, 2007) and cause complexities in the clogging processes. The factor that favours clogging in the case of RBF sites is sustained water extraction. If water extraction continues during a hydrological drought, both rate and scale of river bed clogging increase (Górski \& Przybyłek, 1997).

Clogging in the bed of the River Warta was documented during a hydrological drought in the Kra- 


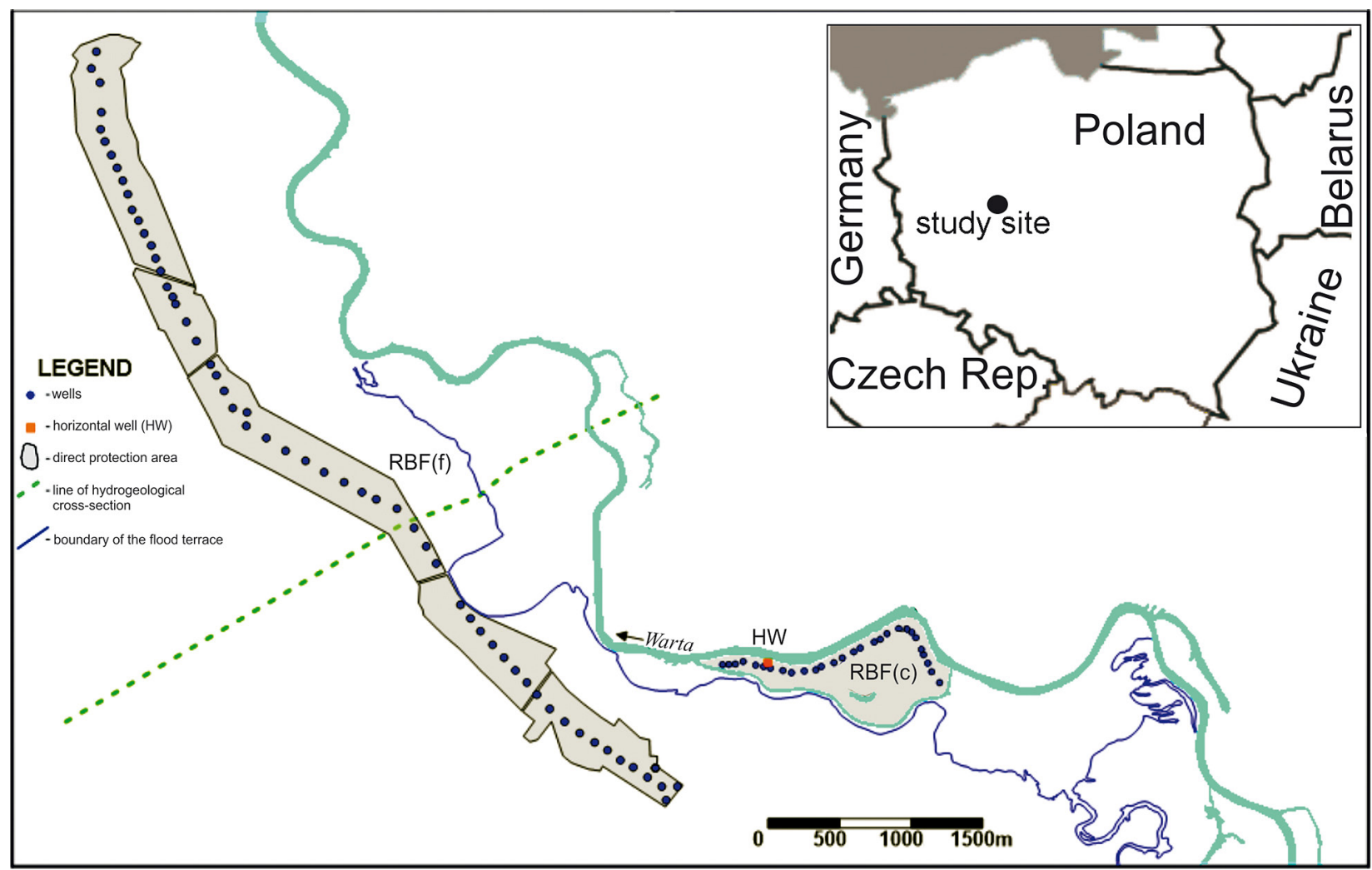

Fig. 1. Location of the Krajkowo well field.

jkowo well field between 1989 and 1992; this well field supplies water to Poznań (Fig. 1). A marked drop in water level was observed after several years of intensive and continuous exploitation of the well scheme, located along the River Warta. An increased rate of well exploitation $\left(136,000 \mathrm{~m}^{3} / \mathrm{d}\right)$ was performed, meeting the high water demand during a drought period. Detailed hydrogeological studies were conducted in order to recognise the origin of the clogging processes as well as to formulate ways of counteracting clogging. The lesser river bed permeability decreased the dynamic water level below the river bed and expanded the cone of depression beyond the opposite river bank to the well scheme.

The aim of the present article is to discuss specific hydrogeological studies that were carried out in investigations of clogging so as to provide guidance for the construction or modernisation of river bank filtration sites.

In view of the methodological range of the research done, the whole investigation was divided into three parts. The present article (part 1) contains results from hydrodynamic investigations, sedimentology research and a geotechnical survey. In part 2, the methodology and results of mineralogical, chemical and hydrobiological investigation of the sediments sampled to $10 \mathrm{~m}$ below the river bed will be presented. Part 3 focuses on the results of groundwater modelling under conditions of clogging of the river bottom as well as after unclogging activities.

\subsection{Clogging processes}

Three main types of clogging processes can be distinguished, i.e., mechanical (physico-chemical), chemical and biological (Heeger, 1973; Beyer, 1977).

Mechanical clogging is caused by concentrations of small grains or colloids in porous media. Small grains can be autochthonous or allochthonous (flowing in river water). In extreme cases, the loose fraction can move within the porous media, creating zonal barriers to water flow (Hewitt, 1963; Sharma \& Yortos, 1987; Skolasińska, 2006). These zonal barriers can also be created by swelling of clay minerals, mainly montmorillonite (Monaghan et al., 1959). Another mechanism of mechanical clogging is the coherence of particles and the bridging of pores. An important role is played by sediment compaction as a result of sustained seepage pressure under conditions of high hydraulic gradients during well exploitation (Glazer, 1985; Piekarski, 2009).

Chemical clogging is caused by precipitation of soluble components (mainly carbonates) onto insol- 
uble grains during changes of hydrogeochemical conditions, which are modified by hydrostatic pressure, redox conditions and temperature changes of infiltrating water. Chemical clogging is extremely effective when the groundwater table lowers to below the bottom of the river and causes an increase in the capillary force in river bed sediments (Hotlos et al., 1983). Under the river bed, an aeration zone is created, which favours soluble component precipitation. This causes a decrease in effective porosity by creating bridges between grains (Biernacka et al., 1993). Chemical clogging can cause the aggregation of small sediment fractions (Przybyłek \& Wojewoda, 1996). This chemical process can also lead to bimodality of sediment grain size distribution (Górski \& Przybyłek, 1992; Skolasińska, 2007).

Biological clogging is caused by the growth, retention and decay of bacteria and algae in river bed sediments, at depths of 1 to 2 metres. This can also be related to the growth of bacteria in river bottom sediments (Górski et al., 1993; Szyper \& Danielak, 1993).

Some authors have defined gas entrapment as a fourth type of clogging (Rinck-Pfeiffer et al., 2000; Grischek \& Bartak, 2016), but this is related mainly to artificial recharge by infiltration pounds and in case of bank filtration can be negligible.

\section{Study area}

The Mosina-Krajkowo well field supplies water to Poznan and is located $20 \mathrm{~km}$ south of the city in the Warszawa-Berlin ice-marginal valley in an area referred to as "Mosina Basin". This basin is crossed by the River Warta (Fig. 1). There are two terraces in this ice-marginal valley area: a flood plain and an upper terrace. The flood plain terrace is $0.5-2 \mathrm{~km}$ wide. Many periodic and long-lasting ox-bow lakes occur on the terraces. In the study area, buried oxbow lakes and 20-m-high sand dunes can be found.

Favourable hydrogeological conditions occur in the study area because the water-bearing sediments of the two main groundwater bodies overlap: the Warszawa-Berlin ice-marginal valley and the Wielkopolska Buried Valley. These aquifers are locally separated by an aquitard composed of glacial tills. Where glacial tills are missing, hydrogeological windows occur. The thickness of the water-bearing sediments in these regions exceeds $40 \mathrm{~m}$. The confining bed of the aquifer is formed by Miocene and Pliocene clays (Fig. 2).

The Mosina-Krajkowo well field is composed of two main well galleries (Fig. 1):

- The well gallery $\operatorname{RBF}(\mathrm{f})$ is located on the higher Warta terrace; it was built between 1968 and 1984. The distance of the wells from the Warta River bank is between 400 and 1,200 m. The length of the well gallery is 7,150 m, and the 56 wells are spaced at distances of 100-150 m (Fig. 1);

- The well gallery RBF(c) is located on the left bank of the River Warta. The 29 wells are located at a distance of $60-80 \mathrm{~m}$ from the river bank. These wells were constructed between 1982 and 1984 . The length of the well gallery is $1,980 \mathrm{~m}$ (Fig. 1).

A horizontal collector well (HW) was built 1988-1991 at river $\mathrm{km}$ 273. Eight horizontal drains are radially located $5 \mathrm{~m}$ below the river bottom. The depths of the horizontal well drains, well screens and the Warta River bottom are illustrated in Figure 3.

From 1990 to 1991 total groundwater extraction was $136,000 \mathrm{~m}^{3} /$ day. The well gallery $\mathrm{RBF}(\mathrm{c})$ contributed with $56,300 \mathrm{~m}^{3} /$ day. Based on groundwater flow modelling results, 75 per cent of the water

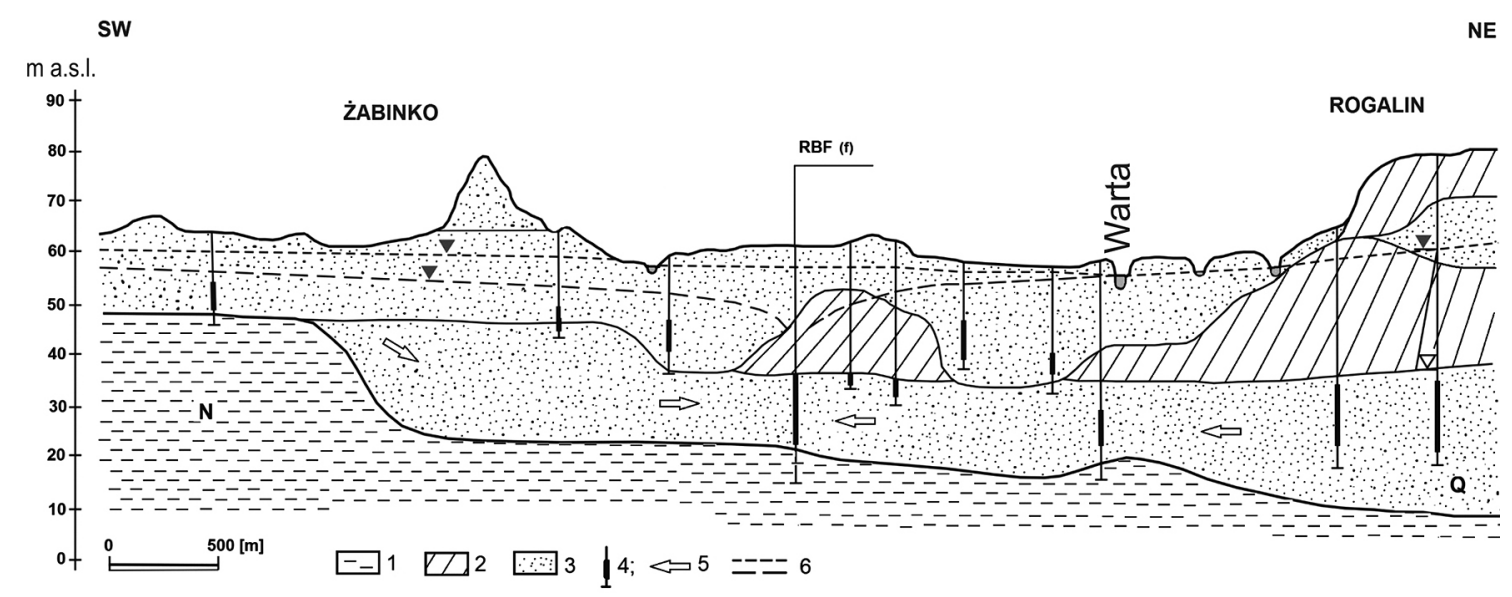

Fig. 2. Hydrogeological cross section (for the line of cross section, see Figure 1). 1 - clay; 2 - glacial tills; 3 - sands and gravels; 4 - well screen location; 5 - main groundwater flow direction; 6 - water level; N - Neogene; Q - Quaternary. 


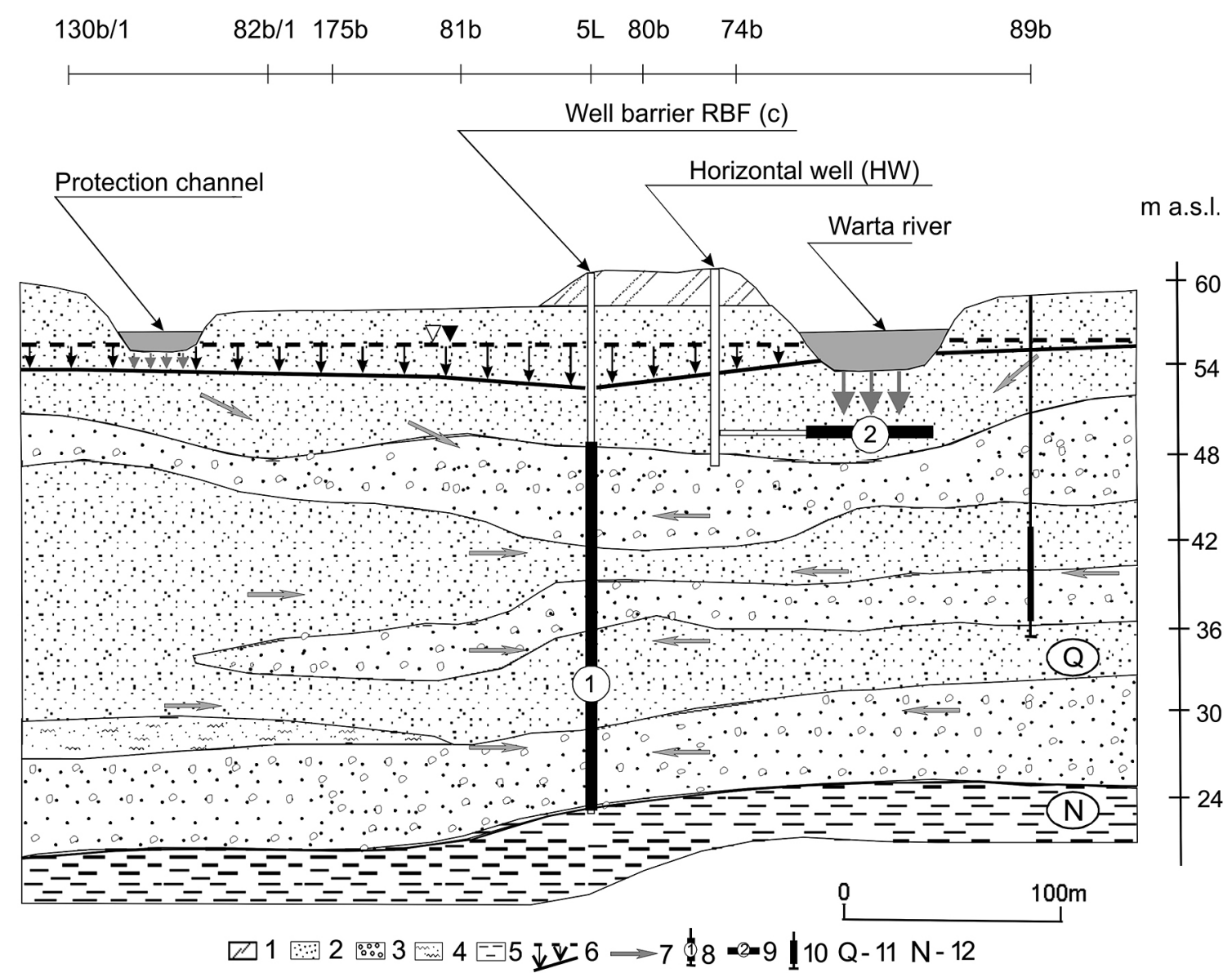

Fig. 3. Location of horizontal drains of the collector well and position of RBF wells (for cross section, see Figure 5). 1- embankment; 2 - sands; 3 - gravels; 4 - silts; 5 - clays; 6 - static and dynamic water level; 7 - groundwater flow direction; 8 - position of RBF well screen; 9 - position of horizontal well screen; 10 - other observation wells; 11 Quaternary; 12 - Neogene.

originated from RBF (Dąbrowski et al., 2011). The reason for the high portion of groundwater extraction was the expansion of the regional cone of depression, which occurred along the Warta River (Figs. 3, 4) from km 265 (at Rogalinek) to $\mathrm{km} 276$ (at Radzewice). In the area of Krajkowo, where the cone of depression was caused by the overlap of the exploitation of two well groups, the cone of depression expanded to the opposite side of the river (Fig. 4).

The main subject of the hydrodynamic analyses presented in this article is the well gallery $\mathrm{RBF}(\mathrm{c})$ on the artificial island that was created after constructing the channel along existing ox-bow lakes (Fig. 5). The entire "Krajkowska Island" is included in the well-head protection zone. The wells are protected against flooding by an embankment. The extracted groundwater is pumped to the water treatment station located approximately $10 \mathrm{~km}$ to the north, at Mosina.

\subsection{Description of the River Warta}

The wells are located at $\mathrm{km}$ 272.6-274.6 along the River Warta. In that region the river meanders through a wide floodplain valley. Basic river training occurred during the nineteenth century. To enable shipping on the river, training structures were built and the river channel was regulated. An average of $1 \mathrm{~km}$ of the water route has 24-36 stone-fascine training structures, with a spacing of $50-60 \mathrm{~m}$. This procedure led to deepening of the river channel in the mainstream part and protected the river bank against erosion (albeit caused erosion of the river bottom). The river channel in the "Krajkowska Island" area has a width of 55 to $70 \mathrm{~m}$ during periods of average and low water levels, and an average depth between 1.1 and $2.1 \mathrm{~m}$ (Table 1).

Characteristic water levels of the River Warta are presented in Table 2 (Przedwojski, 1993). Flow rates of the River Warta correspond to water level changes, both seasonally and over long-term peri- 


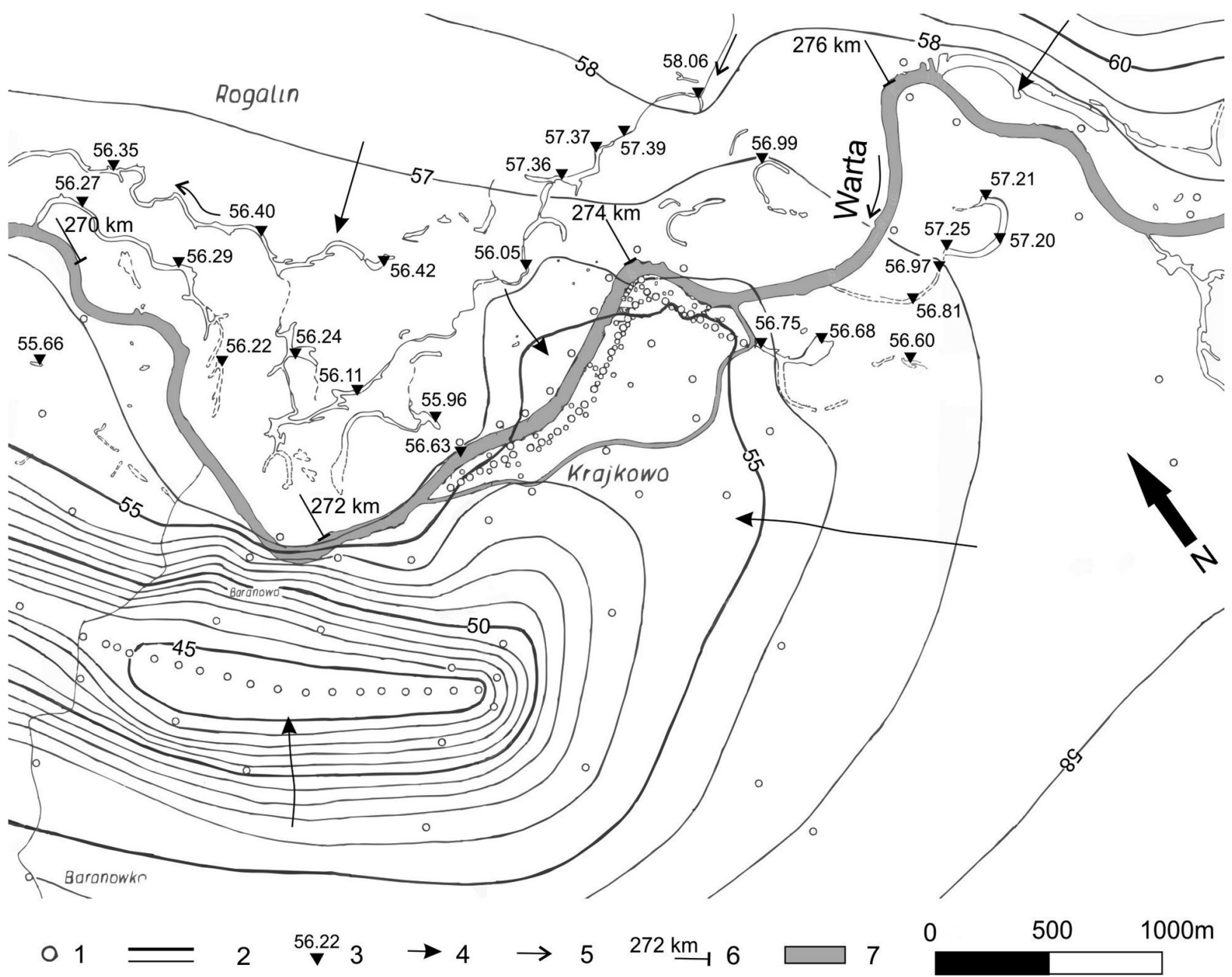

Fig. 4. Piezometric contour map around the Krajkowo well field during drought. 1 - wells and observation wells; 2 piezometric contours [m a.s.l.] (bold line represents $5 \mathrm{~m}$ interval); 3 - surface water level measurement [m a.s.1.]; 4 - groundwater flow direction; 5 - surface water flow direction; 6 - river km mark, 7 - River Warta.

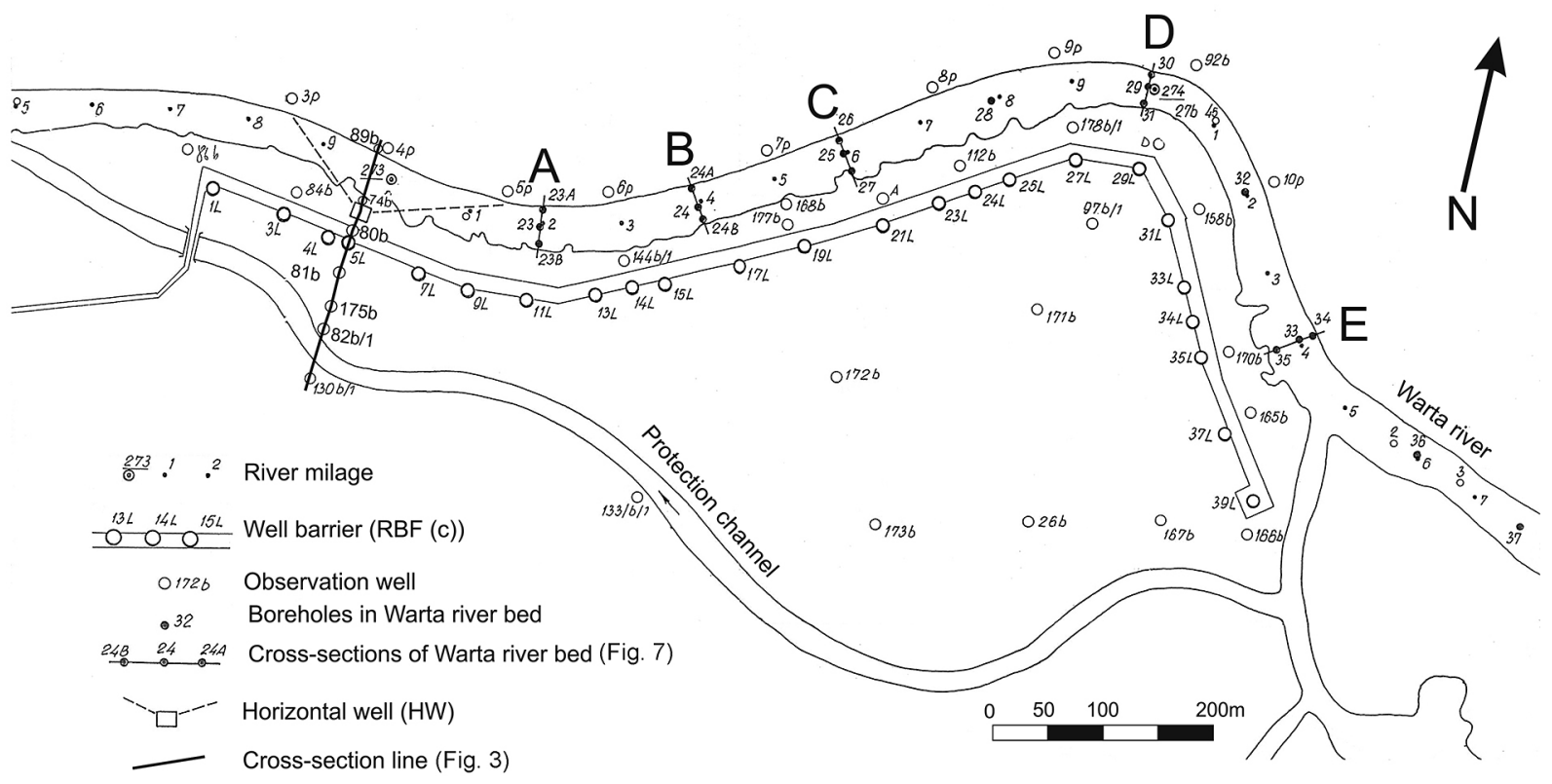

Fig. 5. Sketch of the Krajkowo well field. 
Table 1. Parameters of River Warta bed in hydrological cross sections along the Krajkowo well field (Przedwojski \& Nowak, 1991) (for location of cross sections, see Figure 5).

\begin{tabular}{cccccc}
\hline Cross-section & $\begin{array}{c}\text { River milage } \\
{[\mathrm{km}]}\end{array}$ & $\begin{array}{c}\text { Warta water level } \\
{[\mathrm{m} \text { a.s.1. }]}\end{array}$ & $\begin{array}{c}\text { River depth } \\
{[\mathrm{m}]}\end{array}$ & $\begin{array}{c}\text { River width } \\
{[\mathrm{m}]}\end{array}$ & $\begin{array}{c}\text { Width of river bed } \\
{[\mathrm{m}]}\end{array}$ \\
\hline Transect A & 273.2 & 57.01 & 1.13 & 70.0 & 62.0 \\
Transect B & 273.4 & 57.05 & 1.31 & 60.5 & 53.5 \\
Transect C & 273.6 & 57.07 & 1.55 & 55.0 & 47.5 \\
Transect D & 274.0 & 57.15 & 2.06 & 64.5 & 46.0 \\
Transect E & 274.4 & 57.31 & 1.72 & 79.5 & 58.0 \\
\hline
\end{tabular}

Table 2. Characteristic water levels and flows in the River Warta (Przedwojski, 1993).

\begin{tabular}{cccc}
\hline Water level & Flow $\left[\mathrm{m}^{3} / \mathrm{s}\right]$ & Water level at $272.5 \mathrm{~km}[\mathrm{~m}$ a.s.1.] & Water level at 274.6 km [m a.s.1.] \\
\hline AHW & 340 & 59.18 & 59.55 \\
MW & 86 & 57.33 & 57.75 \\
ALW & 34 & 56.40 & 56.80 \\
LLW & 24 & 56.10 & 56.50 \\
\hline
\end{tabular}

AHW - average high water, MW - mean water, ALW - average low water, LLW - lowest low water.

Table 3. Average grain sizes of the bed load of the River Warta at km 276.2, prior to the startup of the Krajkowo well field (Przedwojski, 1993).

\begin{tabular}{cccccccc}
\hline & \multirow{2}{*}{ Survey date } & \multicolumn{2}{c}{ Flow intensity } & \multicolumn{3}{c}{ Characteristic grain sizes of bed load [mm] } \\
& {$[\mathrm{km}]$} & $\begin{array}{c}\text { Water } \\
\mathrm{Q}\left[\mathrm{m}^{3} / \mathrm{s}\right]\end{array}$ & $\begin{array}{c}\text { River bed load } \\
\mathrm{Q}_{\mathrm{r}}\left[\mathrm{m}^{3} / \mathrm{d}\right]\end{array}$ & $\mathrm{D}_{10}$ & $\mathrm{D}_{50}$ & $\mathrm{D}_{90}$ \\
\hline 15.05 .1982 & 276.2 & 134.0 & 55.4 & 0.245 & 0.394 & 0.795 \\
17.06 .1982 & 276.2 & 86.0 & 17.8 & 0.242 & 0.373 & 0.650 \\
\hline
\end{tabular}

ods (during long wet and dry seasons). During periods of low water levels, the surface of the river bank hydraulic active zone decreases. Due to reduction of the river bank parts where the bank filtration process occurs, accelerated clogging of the river bank and bottom is noticed. The channel bottom of the River Warta consists of fine sands. According to Przedwojski (1993), the average effective grain diameter $\left(\mathrm{D}_{50}\right)$ of the bed load is between 0.37 and $0.39 \mathrm{~mm}$ (Table 3).

A measurement of the bed load was made at the meteorological gauging station on Roch Bridge (20 km downstream, at Poznań) during the years 19731983 (173-223 annual measurements). The average level of the wash load varied from $14 \mathrm{~g} / \mathrm{m}^{3}$ (1982) to $54 \mathrm{~g} / \mathrm{m}^{3}$ (1973) and $26.3 \mathrm{~g} / \mathrm{m}^{3}$, on average (Rocznik hydrologiczny, 1973-1983). Further measurements were performed by Aquanet SA (Poznań waterworks operator) at Dębina 1992-2006 (8-33 annual measurements) and showed results on average of 8 $\mathrm{g} / \mathrm{m}^{3}$ (2001), $33 \mathrm{~g} / \mathrm{m}^{3}$ (1992) and $15.4 \mathrm{~g} / \mathrm{m}^{3}$. The distinct decrease in the wash load is caused by water protection activities (long-term sewage treatment programme) performed in the River Warta catchment after social, economic and political changes occurred in Poland after 1989. It was documented by groundwater mathematical modelling that wells were recharged by $42,200 \mathrm{~m}^{3} / \mathrm{d}$ from RBF 1989 -
1991. Considering the wash load amounts in 1992 and previous years $\left(33 \mathrm{~g} / \mathrm{m}^{3}\right)$, it can be assumed that together with infiltrating water, $1.4 \mathrm{t} /$ day (262 $\mathrm{t} /$ year) of suspended material was infiltrated during the period of 1989-1992 (hydrological drought period).

\subsection{Hydrodynamics and river bed clogging}

From 1987 to 1990, clogging of the bottom of the River Warta became obvious through the systematic decrease in dynamic water levels during constant well operation at Krajkowo. Figure 6 presents a dynamic water level cross section of the wells and the river. The groundwater level was measured in a net of piezometers and in the river in September 1988, June 1989 and June and November 1990. In the first half of the year 1990, the cone of depression in the central part of the well scheme increased to 4 $\mathrm{m}$, and the dynamic groundwater level remained 2 $\mathrm{m}$ below the bottom of the River Warta. The cone of depression expanded beneath the river to the opposite side of the river.

The results of groundwater flow modelling (Dąbrowski et al., 2011) indicate that the strongest decrease in river bed and aquifer permeability was observed along the straight part of the river 


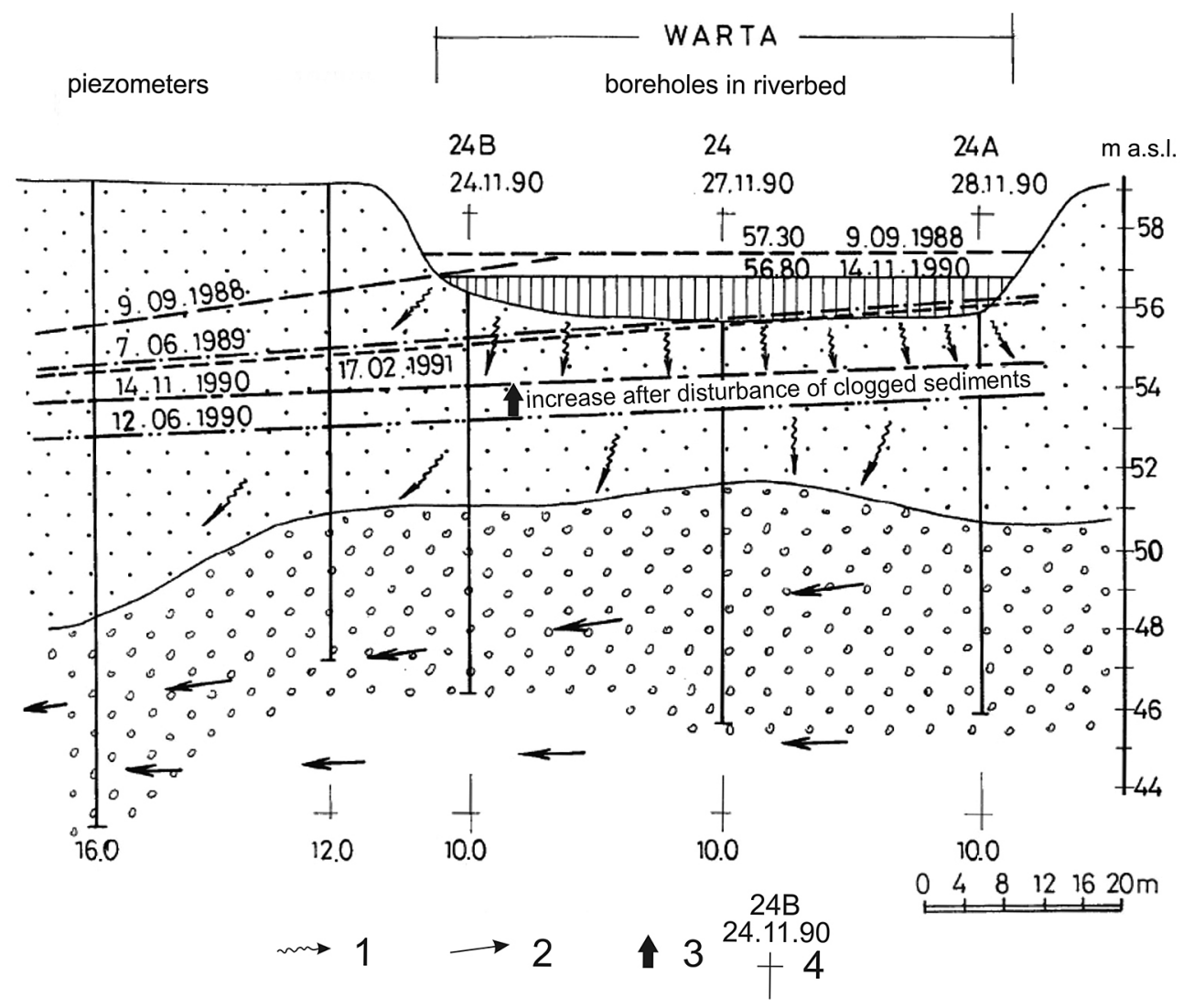

Fig. 6. Cross section with ground and surface water levels between September 9, 1988 and February 2, 1991. 1 - river water infiltration; 2 - groundwater flow directions; 3 - increase of groundwater level after removal of clogged sediments.

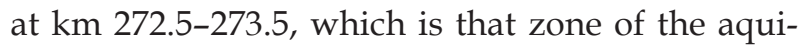
fer where the highest permeability had previously been noted. The hydraulic conductivity in this zone decreased from $1.25^{*} 10^{-4}$ to a range of $1^{*} 10^{-6}-1^{*} 10^{-5}$ $\mathrm{m} / \mathrm{s}$.

\section{Methodology}

Drilling of boreholes was performed between $\mathrm{km}$ 273.2 and $\mathrm{km} \mathrm{274.4}$, in the section adjacent to the well scheme. Drilling was positioned along 1,200 $\mathrm{m}$ in five transects with three boreholes drilled in each transect, located on the line perpendicular to the river channel (Fig. 5). Drilling was performed using pontoon and hand-drilling equipment. Each borehole had a depth of $10 \mathrm{~m}$ below the bottom of the river and was drilled with a $\varnothing 6.5 / 8^{\prime \prime}$ drill pipe. After installation of the drill pipe in the river bed, the river water was exhausted from the pipe, and then drilling was continued without water (dry drilling). The sediment was sampled every run from the river bottom and then every $0.5 \mathrm{~m}$. Each sample was filled to the core box and placed into a plastic bag (for grain size analyses). Clogging products were secured in a glass jar for mineralogical, geochemical and hydrobiological analyses.

Grain size analyses were performed according to the Polish standard in hydrogeology and engineering geology (PN-74/B-02480). In boreholes where an aeration zone was detected $(\mathrm{km} 273.2$ to 273.6), the analyses were carried out for each sample and in the saturation zone in case of lithological changes. A total of 210 grain size analyses were performed, and the grain size distribution was plotted for each sample (Stryczyńska, 1991).

During drilling, a hydrodynamic investigation was also performed. This investigation included measuring of the water level at two reference levels: 1-2 $\mathrm{m}$ below the river bottom and at a depth of $10 \mathrm{~m}$ below the river bottom.

In every borehole location, the dynamic probe DPL (Dynamic Probing Light) was used to a depth of 5 to $10 \mathrm{~m}$ below the river bottom for relative density investigations which matched the standard PN$74 / \mathrm{B}-04452$. The numbering of the DPL probes was the same as that of the boreholes. 


\section{Results and discussion}

\subsection{Hydrodynamic conditions}

The hydrodynamic investigation was performed during and after a long-term hydrological drought, when the regional multi-dimensional cone of depression developed. The interaction between the river and the aquifer during 1990-1991 is illustrated in five hydrodynamic cross sections (Fig. 7) and the lines of the cross section are shown in Figure 5.
Cross section at km 273.2 (Fig. 7 - transect A, boreholes 23B-23-23A) illustrates the cutting of the clogged zone under the river bottom after excavation for installing the horizontal drains of the horizontal collector well. This caused the creation of a local hydrogeological window. The river water infiltration was intensified and caused a rise in groundwater level to $1 \mathrm{~m}$ above the river water bottom (borehole 23) and the disappearance of the aeration zone below the river bottom in this zone. The aeration zone persisted on the left (borehole 23B) and right (borehole 23A) banks of the river.

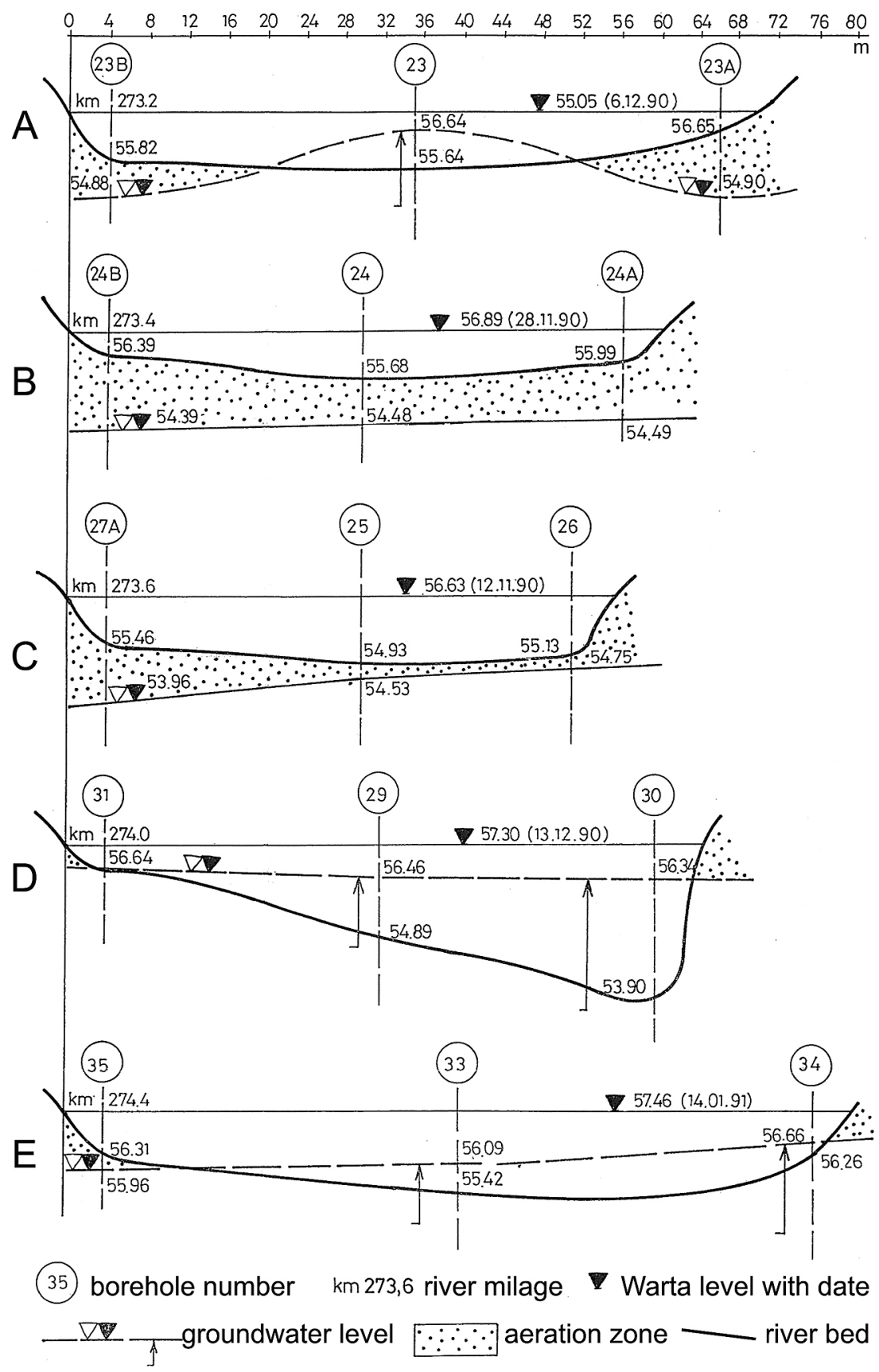

Fig. 7. Hydrodynamic cross sections along transects through the River Warta channel (for position of transects, see Figure 6). 


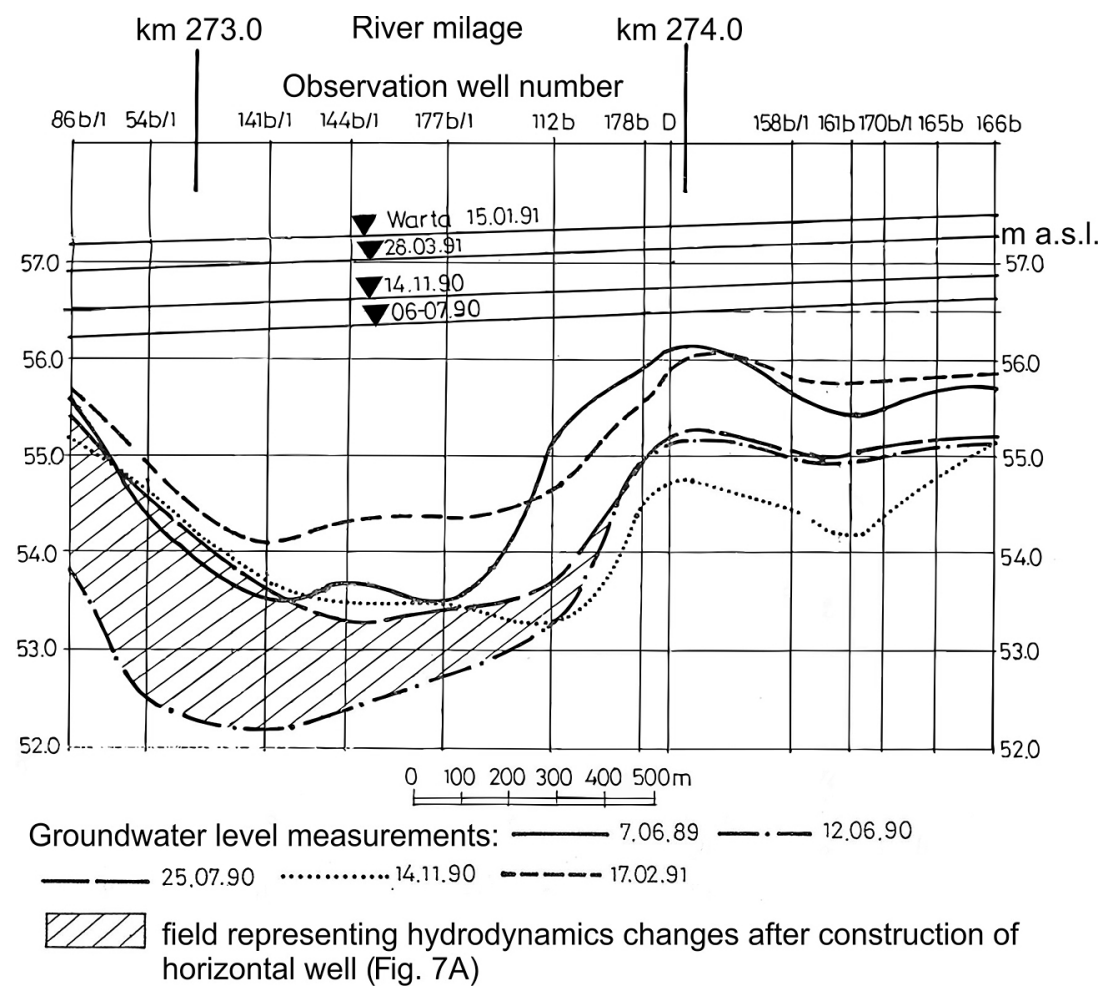

Fig. 8. Ground and surface water level changes from June 7, 1989 to November 17, 1990 along the left river bank.

Cross section at km 273.4 (Fig. 7 - transect B, boreholes 24B-24-24A) expresses the fully developed aeration zone below the river bottom. The thickness of the aeration zone is $2 \mathrm{~m}$ on the left river bank (borehole 24B), $1.2 \mathrm{~m}$ in the central part of the river channel (borehole 24) and $1.5 \mathrm{~m}$ on the right river bank (borehole 24A).

Cross section at km 273.6 (Fig. 7 - transect C, boreholes 27B-25-26A) indicates a high hydraulic resistance in the aquifer (borehole 27A) on the left river bank (from the well barrier site) and a higher infiltration effectiveness on the right river bank (borehole 26). The higher hydraulic gradient indicates a more effective infiltration on the right river bank, where the clogging processes are less severe.

Cross section at km 274.0 (Fig. 7 - transect D, boreholes 32-29-30) illustrates the specific conditions on the bed of the River Warta with an asymmetrical river channel. The static groundwater level occurs above the river bed only $1 \mathrm{~m}$ below the surface water level. The analyses of the interaction of surface and groundwater levels indicate that in this zone, infiltration occurs mainly in places of river channel deepening on the right river bank.

Cross section at km 274.4 (Fig. 7 - transect E, boreholes 35-33-34) indicates that the cone of depression expands through the right bank of the river, but the aeration zone did not appear under the river bottom.
Figure 8 presents results of groundwater level measurements in the piezometers located between the river and the wells during the period between July 1990 and March 1991 together with the river water level. A differentiation of the hydrodynamic conditions is evident along the part between $\mathrm{km}$ 273-274 and km 274-275. Between km 273 and km 274 , the aeration zone beneath the river bottom is caused by overexploitation during conditions of hydrological drought (compare to Fig. 7). Moreover, in this part of the well scheme, a multidimensional cone of depression occurs, which is caused by an overlap of two local cones of depression in $\operatorname{RBF}(\mathrm{c})$ and RBF(f) well galleries. Between $\mathrm{km} 274$ and 275, different conditions occur because the $\mathrm{RBF}(\mathrm{f})$ cone of depression declined at this location and the river stays under the influence of only the RBF(c) wells but with a tendency to cross the right river bank.

\subsection{Results from grain size analyses}

Water-bearing sediments with the largest diversification below the river bed of the River Warta were found in the cross section at km 273.6 (Fig. 7 - transect C, boreholes 27A-25-26).

In Table 4 , the results of grain size analyses of sediment samples are presented. Samples were taken at $0.5 \mathrm{~m}$ below the river bottom up to a depth of 

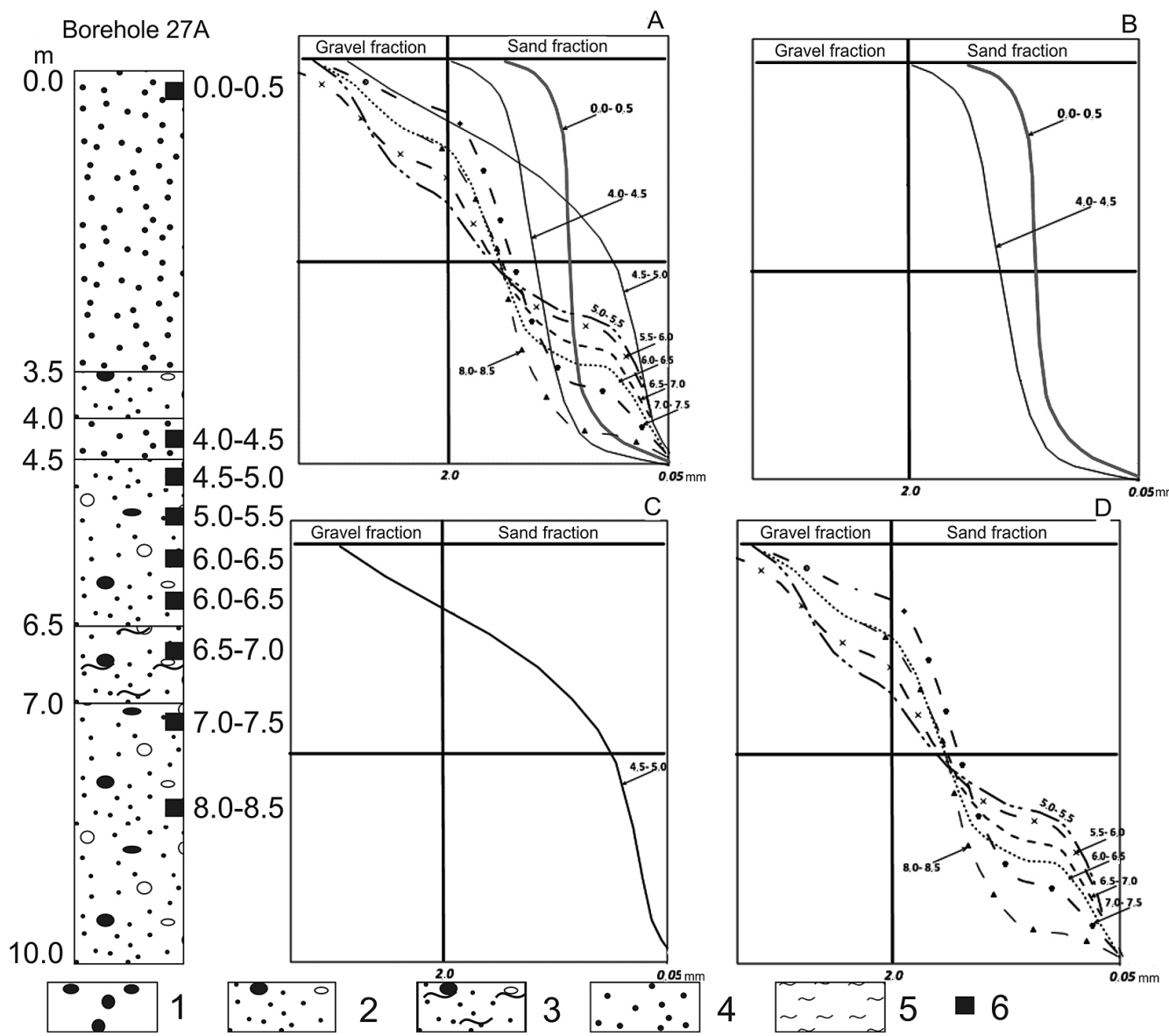

Fig. 9. Grain size curves of samples from borehole 27A (for location, see Figure 5). 1 - gravels; 2 - gravels and sands; 3 - silty sands with gravels; 4 - sands; 5 - silt; 6 - sampling depth.

$10 \mathrm{~m}$. Figure 9 presents the lithological sections of boreholes and four sets of sieve curves. Sieve curves from each sample are shown in Figure 9A, while the sand fraction from $0.0-4.5 \mathrm{~m}$ below the river bed with very even grain size $\left(U=d_{60} / d_{10}\right.$ from 1.7 to 2.59) and small participation of the fraction 0.05 $0.15 \mathrm{~mm}$, up to 1 per cent (Table 4) is illustrated in Figure 9B. Shown in Figure 9C are the sieve curves for layers $4.5-5.0 \mathrm{~m}$ below the river bed, with an enriched amount of the $0.05-0.15 \mathrm{~mm}$ fraction, up to 48.3 per cent (Table 4 ); those from samples $5.0-8 \mathrm{~m}$, where the bimodal distribution is clear, appear in Figure 9D. The portion of the $0.05-0.15 \mathrm{~mm}$ fraction is also enlarged, and grain sizes are very uneven (with $\mathrm{U}=\mathrm{d}_{60} / \mathrm{d}_{10}$ from 10 to 24.6).

This layout states that under the influence of seepage pressure caused by infiltration of surface water, grains of sizes $0.05-0.15 \mathrm{~mm}$ yield suffosion and a clogged (mechanical clogging) sand and gravel zone at a depth of 4.5-8 $\mathrm{m}$, where the filtration of the surface water to the production of the well barrier occurred intensely. Screens of wells are located at corresponding depths to the clogged sediments (Fig. 3).

\subsection{Results from relative density measurements}

Relative density diagrams from the investigation performed in the borehole locations are presented in Figure 10. In the diagrams, additional data are presented relating to water-level measurements and relative density classification: loose sediments, up to 5 blows; medium compacted sediments, up to 20 blows; and compacted sediments, more than 20 blows. From a comparison of each transect, it can be concluded that the compaction of the previously loose sediments occurred within three transects, in regions where an aeration zone under the river bottom was created. The boundary between loose and compacted sediment is clearly visible at depths of $1.0-0.6 \mathrm{~m}$ at $\mathrm{km} 273.2,1.7-0.6 \mathrm{~m}$ at $\mathrm{km} 273.4$ and $0.9-0.6 \mathrm{~m}$ at $\mathrm{km} 273.2$. Up to $\mathrm{km} 273.6$ no compaction of the river bed sediments was observed. Compaction of the sediments on straight stretches of the river was the reason for creating an aeration zone below the river bottom and the expansion of the cone of depression on the right side of the river. In 
Table 4. Grain size analysis of water-bearing sediments and their carbonate calcium content in a section of borehole 27A (for location, see Figure 5) (Stryczyńska, 1991).

\begin{tabular}{|c|c|c|c|c|c|c|c|c|c|c|c|}
\hline \multicolumn{2}{|c|}{ Depth [m] } & \multirow{2}{*}{ Sediment type } & \multicolumn{7}{|c|}{ Percentage of fraction contribution [mm] } & \multirow{2}{*}{$\mathrm{U}=\mathrm{d}_{60} / \mathrm{d}_{10}[-]$} & \multirow{2}{*}{$\mathrm{CaCO}_{3}[\%]$} \\
\hline from & to & & $>0.2$ & $1-2$ & $0.5-1$ & $0.25-0.5$ & $0.15-0.25$ & $0.05-0.15$ & $<0.05$ & & \\
\hline 0.0 & 0.5 & sand & - & 0.5 & 3.5 & 66.3 & 21.2 & 4 & 4.5 & 1.65 & 0 \\
\hline 0.5 & 1.0 & sand & - & 0.2 & 2.4 & 74.4 & 20 & 1 & 2 & 1.30 & 0 \\
\hline 1.0 & 1.5 & sand & - & - & 1 & 65.7 & 31 & 1 & 1 & 1.32 & 0 \\
\hline 1.5 & 2.0 & sand & - & 0.5 & 9 & 71 & 17 & 1 & 1.5 & 1.75 & 0 \\
\hline 2.0 & 2.5 & sand & - & 0.2 & 8.2 & 72 & 17.8 & 1 & 0.8 & 1.90 & 0 \\
\hline 2.5 & 3.0 & sand & - & 0.5 & 9.8 & 76.2 & 12 & 1 & 0.5 & 1.74 & 0 \\
\hline 3.0 & 3.5 & coarse sand & 1.5 & 9.5 & 42.6 & 40.6 & 3.8 & 1 & 1 & 2.07 & 0 \\
\hline 3.5 & 4.0 & coarse sand & 6.5 & 14 & 38.2 & 35.3 & 3.6 & 1.8 & 0.6 & 2.59 & 0 \\
\hline 4.0 & 4.5 & sand & - & 6 & 35 & 50 & 6 & 2.8 & 0.2 & 2.08 & 0 \\
\hline 4.5 & 5.0 & sand and gravel & 13 & 6.6 & 6.9 & 8 & 8.2 & 48.3 & 8 & 3.17 & $3-5$ \\
\hline 5.0 & 5.5 & sand and gravel & 35.7 & 13.3 & 9.7 & 4 & 1.6 & 31.4 & 4.3 & 24.62 & $3-5$ \\
\hline 5.5 & 6.0 & sand and gravel & 30.1 & 17.3 & 12.3 & 5.4 & 2 & 29 & 4.3 & 21.54 & $3-5$ \\
\hline 6.0 & 6.5 & sand and gravel & 22 & 21.7 & 23.3 & 7.3 & 1 & 20 & 4.7 & 15.94 & $3-5$ \\
\hline 6.5 & 7.0 & sand and gravel & 21.2 & 19.1 & 22.6 & 7.5 & 0.9 & 24 & 4.7 & 15.38 & $3-5$ \\
\hline 7.0 & 7.5 & sand and gravel & 12.7 & 17.1 & 33.2 & 16.5 & 1.5 & 15.3 & 3.7 & 10.00 & $3-5$ \\
\hline 7.5 & 8.0 & sand and gravel & 25.8 & 16.2 & 26.7 & 13 & 1.1 & 13.7 & 3.5 & 12.94 & $3-5$ \\
\hline 8.0 & 8.5 & sand and gravel & 25.3 & 17.9 & 33.1 & 14 & 1.7 & 6 & 2 & 4.40 & $1-3$ \\
\hline 8.5 & 9.0 & sand and gravel & 14 & 20.2 & 38.8 & 15.2 & 2 & 7.8 & 2 & 6.00 & $1-3$ \\
\hline 9.0 & 9.5 & sand and gravel & 23.8 & 18.4 & 34 & 13.5 & 1.5 & 8.5 & 0.3 & 5.50 & $1-3$ \\
\hline 9.5 & 10.0 & sand and gravel & 22.5 & 17.3 & 33.2 & 14.7 & 2 & 7.6 & 2.7 & 6.67 & $1-3$ \\
\hline
\end{tabular}

U - Uniformity coefficient

the diagrams, the boundary between the naturally loose and naturally compacted sediments is also indicated (marked by a solid line in Fig. 10). An occurrence of surprisingly loose sediments at greater depths (between 3 and $10 \mathrm{~m}$ ) in borehole locations $23 \mathrm{~B}$ and 23 at $\mathrm{km} 273.2$ was documented. This can be explained by the occurrence of sediments of a buried meander of the River Warta that is crossed by the contemporary river channel. It is a result of technical river trainings performed in the nineteenth century, which caused changes to the natural river channel.

\subsection{Expansion of the cone of depression}

The major reason for expansion of the cone of depression was overexploitation of the aquifer by well fields $\operatorname{RBF}(\mathrm{c})$ and $\mathrm{RBF}(\mathrm{f})$ during the period of long-term regional hydrological drought, between 1989 and 1991. The first symptoms of the cone of depression expansion on the $\operatorname{RBF}(\mathrm{c})$ well barrier were observed in 1989 (Fig. 6), after five years of well-field exploitation. The second reason was the high rate of bed load $\left(31 \mathrm{~g} / \mathrm{m}^{3}\right)$ transported in the river water during the 1980s and 1990s, resulting from domestic and industrial wastewater effluent discharged to the river. A similar situation was documented in other eastern European countries (Grischek \& Bartak, 2016). The suspended and soluble load entered the aquifer together with infiltrating water along the flow path from the river to the wells. The third reason for the expansion of the cone of depression was the long-term, low-flow rate and low water level, which caused limited river bank filtration, due to the reduction of the hydraulic active zone at the river banks. Under such conditions, increased seepage pressure caused suffosion of fine grains, which caused mechanical clogging. The effects of the increased amount of clay minerals (illite and montmorillonite) in river bottom sediments and organic matter, as well as of bacterial growth (Górski et al., 1993), were observed. The diversity of the sediments below the river bottom favoured the washout of fines and their movement to deeper layers of the aquifer where gravels occur. This caused the bimodal sieve curve distributions. The effects of the compaction of originally loose sediments and increased seepage pressure were indicated by the relative density investigation. The evident sediment compaction was documented in three transects (Fig. 10: A, B and C) in the locations where the aeration zone was created below the river bottom (Fig. 7: A, $\mathrm{B}$ and $\mathrm{C}$ ). On the meandering part of the river, this phenomenon does not occur because the asymmetric profile of the river bottom and the deepening of 
A

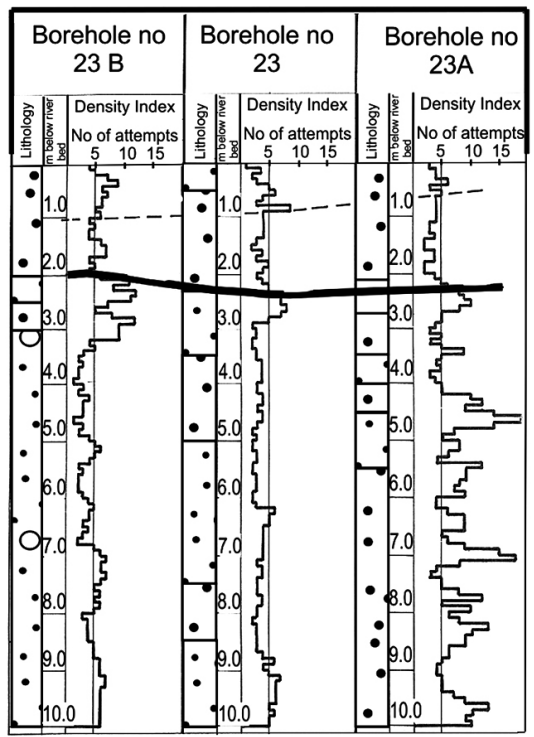

\section{D}

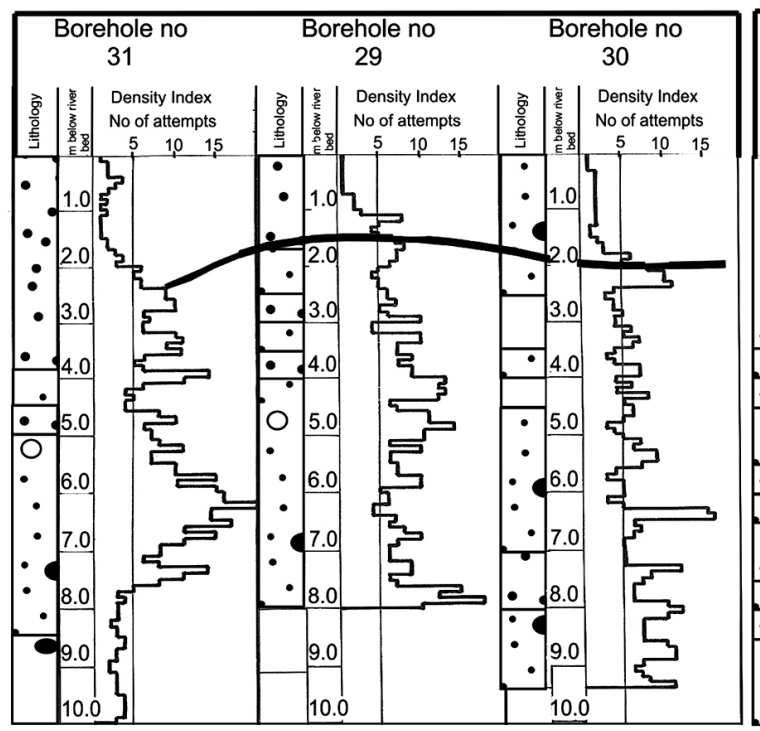

B

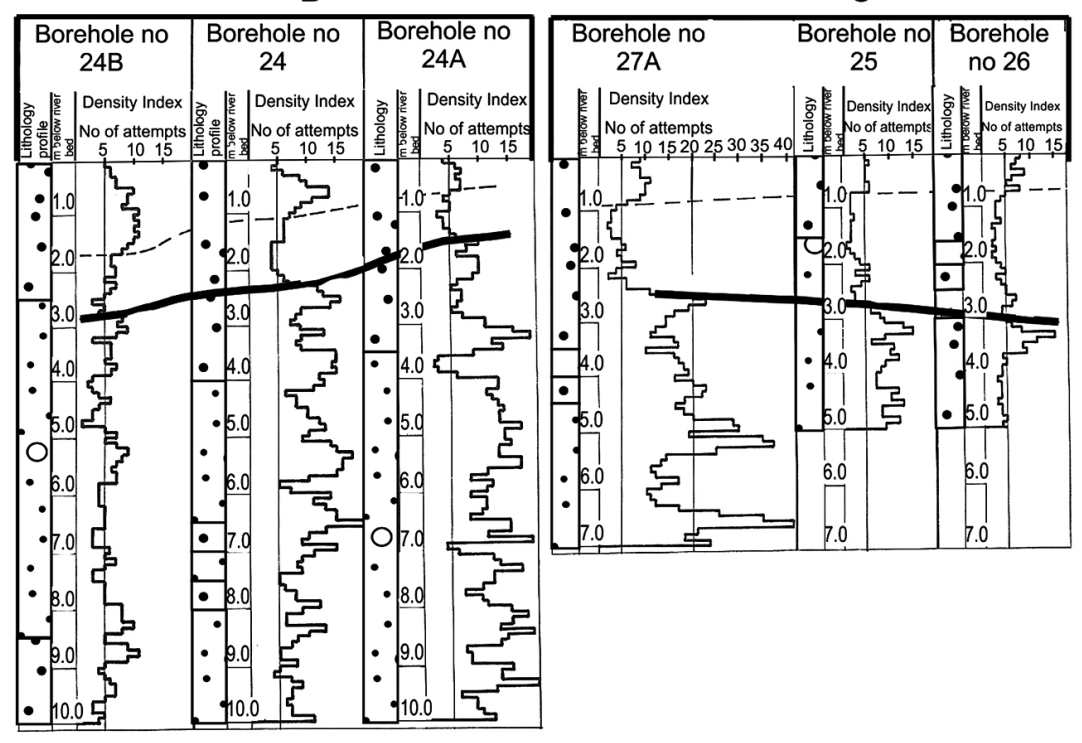

\section{E}

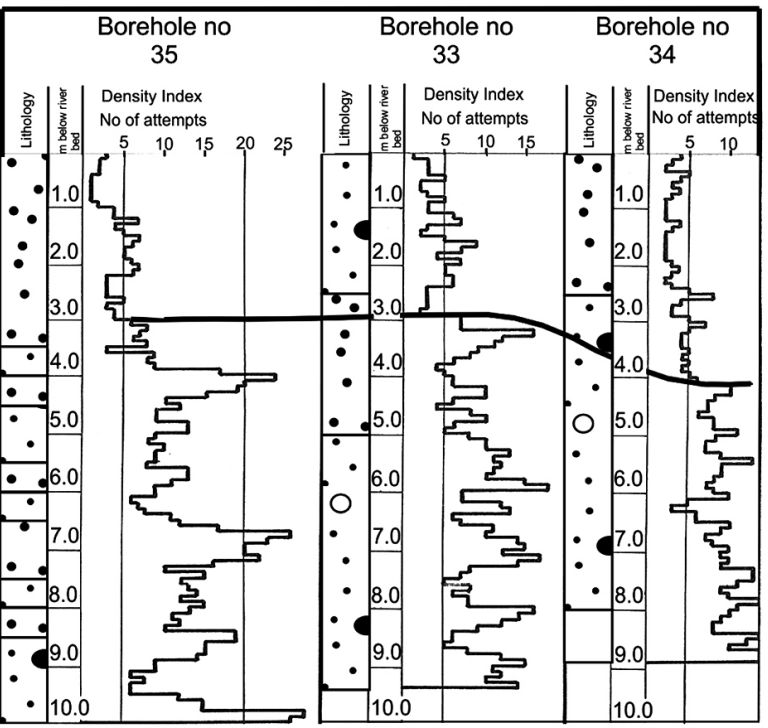

Fig. 10. Relative density diagrams from transects (for location of transects, see Figure 5). Solid line - boundary between naturally loose and naturally compacted sediments; dotted line - depth of clogged sediments.

its channel cause a high water flow velocity. It does not favour the shallow sediment clogging but does cause the deeper penetration of suspended materials in the aquifer in the direction to the well screens located on the river meander.

The hydrodynamic effect of these conditions was the creation of the aeration zone below the river bottom for a length of $400 \mathrm{~m}$ along $\mathrm{km} \mathrm{273.3-273.7}$ (Fig. 8) and expansion of the cone of depression on the side of the river opposite to the well barrier. It led to a drop in water level and drying of oxbow lakes in a unique landscape. Surface water levels in the oxbow lakes are presented in Figure 4. The range of the cone of depression is indicated on the water level contour map by the location of the $55 \mathrm{~m}$ a.s.l. contour (Fig. 4). This piezometric contour line, equal to the river water level, proved the expansion of the cone of depression for a distance of several hundred metres from the river channel. The depth of the cone of depression at the wells was exceeded from an assumed $2 \mathrm{~m}$ to measured more than $4 \mathrm{~m}$.

The investigation has resulted in the formulation of guidelines, schedules and definition of the parts of the river for unclogging activities (Przedwojski, 1993).

In July 1990, dredging of the bottom of the River Warta started. It was related to the construction of a collector well along $\mathrm{km} 273$ of the river. To install 
the drains below the river bottom, sediments were removed to a depth of $5 \mathrm{~m}$. This led to restoration of the pathway for infiltrating water through the local hydrogeological window within the clogged sediments. The effects were almost instantaneous, as an increased dynamic water level was observed (Figs. $6,7 \mathrm{~A})$. The hydraulic rinsing and loosening of the river bottom sediments at a depth of 1.5-2.0 m was also performed with the use of a special technical ship, "Wodnik".

The effectiveness of the unclogging activities is documented by comparing the groundwater level in the observation wells (Fig. 8), which are located between the river and well 14L (Fig. 5). A groundwater level increase is clearly observed after the construction of the horizontal well drains and the unclogging activities along the part of the river between transects A and C (Fig. 7). These activities also led to the reinstatement of the hydraulic contact between the aquifer and the river.

\section{Conclusions}

A special hydrogeological investigation of the bottom of the River Warta (Krajkowo well field, Poland) and the aquifer was performed at river $\mathrm{km}$ 273.2 and 274.4. The investigation included drilling of boreholes along five transects located perpendicular to the river and relative density measurements performed using a dinghy.

Two layers of sediments were recognised, both in facies distribution and grain size: an upper, finegrained layer package and a deeper, coarse-grained layer (fine and medium sand and gravel). The bimodal type of the sieve curve distributions is indicative of the migration of fine fractions from the upper, fine-grained to deeper, coarse-grained sediments, resulting in deep clogging.

An aeration zone below the river bottom was proved by groundwater level measurements performed on each transect at a depth of $10 \mathrm{~m}$ below the river bottom in that part of the river situated between $\mathrm{km} 273.3$ and 273.7, where infiltration of river water decreased significantly.

Sections of the river channel with previously loose sediments were compacted because of mechanical clogging, which was documented by relative density measurements. This type of shallow clogging is a periodic phenomenon on the rectilinear part of the river channel. Natural unclogging occurs during floods and causes deep river bottom erosion. Unclogging can also be performed by artificial hydraulic dredging, which causes rinsing and loosening of the river bottom sediments.
Unclogging of the river bottom was also observed during construction of the horizontal well drains, completed by the trench method, which caused the increase in the groundwater level in its vicinity.

\section{Acknowledgements}

Preparation of this paper was supported by the AquaNES project, which has received funding from the European Union's Horizon 2020 Research and Innovation Program, under the grant agreement no. 689450.

\section{References}

Beyer, W., 1977. Kolmatacja koryt wód powierzchniowych przy eksploatacji ujęć infiltracyjnych [Clogging of surface water channels connected with bank filtration sites]. Technische Universität Dresden, PH Poznań, Archive of Institute of Geology AMU, Poznań, 30 pp. Translation from German.

Dąbrowski, S., Kapuściński, J., Nowicki, K., Przybyłek, J. \& Szczepański, A., 2011. Metodyka modelowania matematycznego w badaniach $i$ obliczeniach hydrogeologicznych - poradnik. [Methods of mathematical modeling in hydrogeological research and calculation]. Ministerstwo Środowiska, Warszawa, 364 pp.

Glazer, Z., 1985. Mechanika gruntów [Soil mechanics]. Wydawnictwo Geologiczne. Warszawa, 328 pp.

Górski, J. \& Przybyłek, J., 1992. Procesy kolmatacji osadów w dnie Warty wzdłuż infiltracyjnych ujęć wody dla Poznania [Clogging proceses in Warta river bed sediments along river filtration sites for Poznań]. [In:] Zaopatrzenie miast $i$ wsi $w$ wode [Water supply of towns and villages], Naczelna Organizacja Techniczna, Poznań, 242-249.

Górski, J., Przybyłek, J. \& Szyper, H.,1993. Organizmy planktonowe $\mathrm{w}$ wodach podziemnych i utworach wodonośnych na ujęciu infiltracyjnym w Krajkowie [Planktonic organisms in groundwater and aquifer sediments at Krajkowo well field]. [In:] Biologia $i$ monitoring wód podziemnych [Biology and monitoring of groundwaters], Naczelna Organizacja Techniczna, Częstochowa, 53-56.

Górski, J. \& Przybyłek J., 1997. Wpływ suszy w latach 1989-1992 na warunki eksploatacji infiltracyjnych ujęć wody w dolinie Warty [The influence of 19891992 years drought on exploitation conditions of infiltration water intakes in the Warta River valley]. [In:] Górski, J. \& Liszkowska, E. (Eds): Wspótczesne Problemy Hydrogeologii 7, 1-8

Grischek, T. \& Bartak, R., 2016. Riverbed clogging and sustainability of riverbank filtration. Water 8, 604

Heeger, I., 1973. Methodik zur Erkundung von Uferfiltratvorraten. VEB Hydrogeologie Nordhausen. Arbeitsstelle Dresden, 221 pp. 
Hewitt, C.H., 1963. Analytical techniques for recognizing water sensitive reservoir rocks. Journal of Petroleum Technology 15, 813-828.

Hiscock, K.M. \& Grischek, T., 2002. Attenuation of groundwater pollution by bank filtration. Journal of Hydrology 266, 139-144.

Rocznik hydrologiczny 1973-1983 [Hydrological year-book 1973-1983]. Państwowy Instytut Hydrologii i Hydrogeologii, Warszawa,

Hubbe, M.A., Chen, H. \& Heitmann, J.A., 2009.Permeability reduction phenomena in packed beds fiber mats, and wet webs of paper exposed to flow of liquids and suspensions: a review. BioResources 4, 405-451.

Kowal, A.L. \& Świderska-Bróż, M., 1997. Oczyszczanie wody [Water treatment]. Wydawnictwo Naukowe PWN, Warszawa, 614 pp.

Monaghan, P.H., Salatheil, R.E. \& Morgann, B.E., 1959. Laboratory studies of formation damage in sands containing clays. Journal of Petroleum Technology 11, 209-215.

Piekarski, J., 2009. Analiza wybranych parametrów kolmatacji w procesie filtracji grawitacyjnej [Analysis of selected parameters of colmatation in the process of gravitational filtration]. Rocznik Ochrony Środowiska 11, 421-437.

Przedwojski, B., 1993.Charakterystyka hydrogeologiczna $i$ hydrauliczna Warty [Hydrogeological and hydrodynamical characteristics of Warta river]. Polskie Towarzystwo Geologiczne, Poznań, 36-49.

Przybyłek, J. \& Wojewoda, J., 1996. Zmiany pierwotnych cech osadów wodonośnych w dolinie Warty oraz objawy spadku ich przepuszczalności w strefie ujęcia wody dla miasta Poznania w Dębinie II [Changes of primary features of water-bearing sediments in Warta valley and premises of drop in hydraulic conductivity in Dębina well field]. [In:] Municipal and rural water supply and water quality. Poznań, 129-145.

Rinck-Pfeiffer, S., Ragusa, S., Sztajnbok, P. \& Vandevelde, T., 2000.Interrelationships between biological, chemical, and physical processes as an analog to clogging in aquifer storage and recovery (asr) wells. Water Research 34, 2110-2118.
Sharma, M.M. \& Yortos, Y.C., 1987. Fines Migrations in Porous Media. AIChE Journal 33, 1654-1662.

Skolasińska, K., 2006. Clogging microstructures in the vadose zone - laboratory and field studies. Hydrogeology Journal 14, 1005-1017.

Skolasińska, K., 2007. Review of Permian sedimentary successions of Boskovice Trough, Nachod Basin and Trutnov Basin. Sedimentologica 1, 5-17.

Sprenger, C., Lorenzen, G., Hulshoff, I., Grutzmacher, G., Ronghang, M. \& Pekdeger, A., 2011. Vulnerability of bank filtration systems to climate change. Science and the Total Environment 409, 655-663.

Sroka, Z., Walczak, Z. \& Wosiewicz, B., 2014. Description and application of a model of seepage under a weir including mechanical clogging. Journal of Water and Land Development 21, 3-9.

Stryczyńska, M., 1991. Sprawozdanie z wierceń w dnie rzeki Warty w rejonie ujeccia brzegowego w Krajkowie [Report from drilling in the Warta river bed around Krajkowo well field]. Przedsiębiorstwo Geologiczne we Wrocławiu, Oddział w Poznaniu, 6 pp.

Szyper, H. \& Danielak, K., 1993. Pojawianie się organizmów w ujmowanej wodzie a problemy eksploatacji ujęć wód podziemnych [Appearance of organisms in captured water and problems of groundwaters exploitation]. [In:] Biology and monitoring of groundwaters, Naczelna Organizacja Techniczna, Częstochowa, 57-59.

Trzaska, A. \& Sobowska, K., 2000. Kolmatacja. Przepływy z wymianą masy i zmianą jej objętości [Clogging, flows with the exchange of mass and change its volume]. Archives of Mining Sciences 45, 527-542.

Ulrich, C., Hubbard, S.S., Florsheim, J., Rosenberry, D., Borglin, S., Trotta, M. \& Seymour, D., 2015. Riverbed clogging associated with a California riverbank filtration system: an assessment of mechanisms and monitoring approaches. Journal of Hydrology 259, 1740-1753. 